\title{
Empowerment Model of Rural Cattle Breeders in Livestock Waste Management \\ (Case Study in the village of Waturejo, Ngantang, Malang Regency)
}

\author{
Ajik Siswantoro $^{1^{*}}$, Yayuk Yuliati \\ ${ }^{1}$ Post Graduate Program in Agricultural Sociology, Faculty of Agriculture, Brawijaya University, \\ ${ }^{2}$ Department of Social Economics, Faculty of Agriculture, Brawijaya University, Jl. Veteran, \\ Malang, 65145, Indonesia
}

Received: 2 February 2017; Revised: 27 April 2017; Accepted: 1 Agustus 2017

\begin{abstract}
Livestock activities in rural areas are often less concerned with good waste management. It is noted that one adult cow can produce $15-25 \mathrm{~kg}$ of dung per day. With the number of cattle population reaching 14,140 heads, the cattle dung collected per day amounts to 353.5 ton. If the waste of cattle dung is not properly utilized, it can have a serious impact on people health and cause environmental pollutions. This research was aimed to understand how community activities were run in utilizing and managing the waste of cattle dung and to formulate models of community empowerment in the waste management of cattle dung. This research used a qualitative approach. The determination of informants was conducted by way of snowball sampling while the data analysis used the model of Miles and Huberman. The results of the research in the field found that the community was still not maximal in the waste utilization of cattle dung. In contrast, the community preferred to dispose of the waste instead of utilizing it into manure or organic fertilizer. The effort of making biogas reactor has not been able to help the community utilize the waste maximally. As an effort to protect the environment from the great deal amount of cattle dung, a model of Rumah Pupuk Masyarakat (RPM) - Community's Fertilizer House - was formed in order to overcome the problem of cattle dung, which has not been maximized properly in the site of the research.
\end{abstract}

Keywords: environment; waste; environmental impact

\section{How to cite:}

Siswantoro, A., \& Yuliati, Y. (2017). Empowerment Model of Rural Cattle Breeders in Livestock Waste Management ( Case Study in the village of Waturejo , Ngantang, Malang Regency ). HABITAT, 28(2), 54-60. https://doi.org/10.21776/ub.habitat.2017.028.2.8

\section{Introduction}

The sector of livestock has become a national issue in relation to the supply of beef in the Eid season. During the season, the supply of beef is likely to experience many shortages, causing the price of beef significantly increases. As an effort to overcome this issue, the government has made a policy to import beef. It intends to stabilize the beef market price.

The policy to import beef has made pros and cons in the environment of small farmers (cattle breeders), which is considered to be financially detrimental to them. Many cattle prices are played by middlemen so that the cattlesmall breeders have to lose a considerable

"Corresponding Author

E-mail: ajik_siswantoro@yahoo.com amount of money. The absence of a management sector on livestock that is fully controlled by the state is one of the problems that must be solved. Ngantang District is one of the areas in Malang Regency where most of the communities work as farmers and dairy cattle breeders. Almost half of the population raises dairy cattle either as the main income or additional income. Based on the data in 2013, the number of cattle in Ngantang District was 14,140 heads (BPS, 2014). It is likely that the number will increase as the needs of beef and milk also continue to increase. Given the enormous potentials in livestock centers, the government should be able to take on the role of overcoming the existing problems.

The considerable number of cattle does not also escape from the problems resulted. The most classic problem is related to the waste management of cattle dung. (Fianda et al, 2013) stated that one adult cow can produce $15-25 \mathrm{~kg}$ of 
dung per day. Given the number of cattle population reaching 14,140 heads and the dung produced by a cow amounted to $25 \mathrm{~kg}$ per day, it can be calculated that the total amount of cattle dung collected per day will be 353.5 ton. If this livestock waste is not utilized well, it will negatively affect the people health and cause environmental damage.

According to (Juheini, 1998), 56.67\% of cattle breeders dispose of their cattle dung into river bodies without management, resulting in environment pollutions. Pollutions caused by livestock activities primarily derive from the waste produced by livestock animals (cattle) including feces, urine, feed residue, and residual water of cattle and cage cleaning. The presence of pollution caused by the waste of cattle breeding often results in various protests from the surrounding community due to the strong smell and itchiness when using contaminated river water.

Based on the background above, the purpose of this research was to identify the community activities in managing the waste of cattle breeding (cattle dung) and to design the mentoring model for the community in protecting the environment from the abundance of livestock waste that was not well utilized.

\section{Research Method}

\subsection{Research Site and Time}

This research was conducted in Waturejo Village, Ngantang District, Malang Regency, East Java. The site selection was based on the considerable number of cattle breeders. It can be said that a lot of cattle dung or waste produced in this village had not been fully utilized. As the consequence, it could disrupt the existing ecosystems of the surroundings, called as environmental damage.

\subsection{Informant Determination Method}

Determination of informants in this research used snowball sampling technique. A snowball sampling technique is a process of collecting data with a small amount. However, if the information is considered less, the data collection can be enlarged by adding other informants that can support the research data. The number of informants or respondents in this research was 14 people covering village apparatus or officers, cattle breeder groups, cattle-small breeders, and the KUD (Village Unit Cooperative).

\subsection{Data Collection Type and Technique}

Data used for this research included primary data and secondary data. The primary data collected by observation technique, unstructured and structured interview with the breeders. The secondary data consisted of physical environmental conditions of the research site, socioeconomic conditions of the community and other data to support the research results either available at the village, district or other related institutions.

\subsection{Data Analysis Method}

The method of data analysis used in this research was descriptive qualitative method according to Miles and Huberman's (Sugiyono, 2014). According to Miles and Huberman's, data analysis is done with qualitative data reviewers, covering data collection, data reduction, data presentation, conclusion drawing or verification.

\section{Results and Discussion}

\subsection{Community Activities in the Waste Management of Cattle Dung}

The effort of preserving the environment is a part of human life. Maintaining the environment can be done by living side by side with the environment without damaging each other (Mirza, 2015). Efforts made by the community of Waturejo Village in maintaining the environment was only limited to the awareness of each breeder. The community of Waturejo Village tended to utilize cattle dung into biogas material and manure (fertilizer). If the cattle dung was utilized into biogas material, the waste would be dumped into the water channels around the settlement. Even the waste of biogas that still could be utilized into fertilizer was also dumped by the breeders. The waste utilization of cattle dung was only limited to the willingness and necessity of each individual breeder.

Nowadays, the waste utilization of cattle dung as manure (organic fertilizer) begins to decrease. Farmers prefer to use chemical fertilizers. The fast process and more affordable price are some of the reasons why they tend to use chemical fertilizers. The views above have made the waste utilization of cattle dung become very limited. Instead, the waste of cattle dung is thrown away without being utilized.

The livestock waste management is influenced by some factors covering the characteristics of breeders, the characteristics of 
livestock waste management innovation, and the environmental conditions. Partially, the contribution with the strongest influence is indicated by the factor of environmental conditions in which the existence of conformity between the social system, physical condition, economic condition and the role of government can encourage the implementation of livestock waste management (Asep et al., 2013).

The behavioral pattern of Not In My Back Yard (NIMBY) stating an idea that the most important is to not dump a lot of livestock waste around my own place' is a classic problem that is hereditary performed by breeders. Breeders are less concerned on the waste utilization of cattle dung. In contrast, they always dispose of the waste of cattle dung into the ditches. This destructive activity occurs almost every day.

The way to think that 'the most important is to not dispose of livestock waste in my own place (breeders)' negatively affects the other people. Non-breeders often have to bear the impact of livestock waste disposal because the water channels in front of their houses are clogged with the waste. The ditch blockage makes the waste (cattle dung) spilled into the road, causing the environment dirty and smelly (Amang Fathurrohman et al.,2016). People still often less understand the benefit of cattle manure and biogas. People tend to have a negative view of waste due to its smell and form.

In fact, if breeders can utilize the livestock waste into fertilizer, it will increase their income. Furthermore, using organic fertilizer will help maintain public and environmental health around the livestock farm. According to (Sholihul, 2016), cattle dung can produce NH3. If combined with dust in a long-term, $\mathrm{NH} 3$ will cause several diseases of lungs and air pollution.

Furhermore, (Indri A, et al., 2015) stated that people mostly understand the benefit of the waste of dairy cattle dung, but they do not understand how to utilize it so that they cannot fully get the benefit resulted from its utilization. The waste-liquid form makes people lazy to take advantages of it. This causes the waste utilization among people still low.

Actually, if cattle breeders can make additional treatment such as utilizing it into organic fertilizer, it will give a better result and additional economic value (Ananto et al., 2013). Cattle manure (fertilizer), which is organic, is very good for the farming of vegetable crops. Moreover, cattle manure (fertilizer) is easy to get because the price is cheap and the benefit is real.

\subsection{Parties Involved in Waste Management for Environmental Protection}

The higher level of education owned by a person in livestock business will result in greater effort to utilize livestock waste so as not to damage the environment. The effort in protecting the environment from the abundance of cattle dung disposal is not solely the duty of cattle breeders. There are also other parties involved in dealing with the problem of cattle dung disposal. In the research site itself, the related parties involved in cattle waste management for the environmental protection consisted of the village apparatus, Village Unit Cooperative $(K U D)$ of Sumbermakmur, and Jasa Tirta (State Owned Enterprise of Water Resource Management) manager of Ngantang District. The three parties play different roles in the waste management. The roles and tasks are adjusted to the respective the engagement level of the main duties and functions. There must be a clear division of tasks from each community element related to the problem of cattle dung management. This is necessary in order to avoid the overlapping work among each community element involved. Additionally, the division of the main duties and functions is aimed at the control when things go wrong or activities do not work well.

Based on the identification of the research site, the Government of Waturejo Village still only focused on the improvement of drainage channels around the community. The purpose of the focus was to avoid the occurrence of ditch blockage caused by the waste disposal of cattle dung, given the fact that the community often disposed of the waste of their cattle dung into ditches so that the construction of irrigation channels around the settlement needed to be realized immediately.

The Village government appealed to the breeder community to protect the environment from the waste abundance of cattle dung. The purpose was to make the community's environment clean from the waste. The Village Government also conducted training on how to make composted fertilizer (organic fertilizer) in the community but it did not attract the community of Waturejo Village to implement it.

The KUD of Sumbermakmur, as the partner of breeders, then tried to look for a new breakthrough or alternative in the waste utilization of cattle dung. The effort to process the waste into biogas was one of the superior ways that $K U D$ did in the waste utilization of 
cattle dung. The $K U D$ was the partner that helped the breeders to make biogas reactor by giving money loan. The process, at least, could help them in protecting the environment from the livestock waste (cattle dung) that was previously dumped without utilization but now it has been processed into biogas. However, the existence of biogas reactors also caused obstacles. The liquid waste produced from biogas reactors also still did not attract the community to utilize it. Instead, this waste was again thrown away without being processed.

Meanwhile, the Jasa Tirta that has the function to utilize the water flow from Konto Watershed and several tributaries did not emphasize on the impacts of livestock waste (cattle dung). In fact, the impacts were very real and able to be perceived by the Jasa Tirta. Some of the impacts included reservoir siltation and a great amount of water hyacinth plant growing in the dry season. Nevertheless, there have been no concrete steps from the Jasa Tirta to respond the problem of the waste management of cattle dung. So far, there has been no counseling and mentoring activities provided by the Jasa Tirta on how to process and manage the waste well so as not to impact on the environment. In contrast, the Jasa Tirta tended to emphasize on dredging the reservoirs due to the great deal amount of waste settled in the reservoirs. The Jasa Tirta considered that the activities of counseling and mentoring of livestock waste management to the community did not include to their responsibility. The emphasis made by the Jasa Tirta was only on the water availability to supply the hydropower need.

\subsection{Community Contribution in the Environment}

To solve the problem of the waste management of cattle dung, there were many ways conducted by the community of Waturejo Village. From the research results in the field, the contribution given by the community could be in the form of money or energy, depending on each individual. The contribution was a form of environmental awareness of the livestock activities that have been performed in the area. The community was aware that the disposal of the waste of cattle dung into ditches would result in negative impacts. The awareness was based on the fact that the amount of livestock waste produced every day was very great. In another side, the land of waste disposal was very limited. This made the community forced to dispose of the waste of their cattle dung into ditches, which was then taken along to rivers because the community did not know anymore how to process their cattle manure waste so as not to damage the environment around their houses.

The direct contribution of the community to maintain their environment was mostly in the form of energy or effort to carry out drainage channel improvement activities around the settlement. The community was willing to repair the ditches around their settlement so that there would be no blockage in the process of cattle dung disposal. The activities of cleaning ditches were done once a month as a form of preserving the environment from the waste of cattle dung. The research results in the field found that if the community could not directly participate in the drainage channel improvement activities, they could substitute it with money donation. The small breeders were willing to set aside a little of their income obtained from livestock activities as much as $\mathrm{Rp} 10,000$ - Rp20,000. The contribution in the form of money is expected to be used to finance the drainage channel improvement. In another side, the community who owned a considerable number of cattle was also ready to contribute. Different from the small breeders, the middle-class breeders with average incentives were willing to set aside their income of cattle breeding activities as much as Rp25,000 Rp50,000 even more. However, according to the results of interviews, the contribution given by the breeder community was, at least, in line with the level of their livestock ownership. There were even some people who brought cement as their contribution to the improvement of sewerage disposal channels.

This indicated that the community was aware of the importance of protecting the environment from various threats, including the waste of cattle dung. We can imagine, if there are 500 breeders in Waturejo Village and each of them can contribute Rp10,000 per month, the total donation to be obtained will be Rp5,000,000 per month. This is a new breakthrough that people can independently overcome the management problem of livestock waste. The potential donation can be maximized to make the environmental protection run well.

In the effort of protecting the environment from the waste of cattle dung, an institution that is able to help the community in managing the donated funds to overcome the livestock management problem is really needed. The community hopes that the waste utilization into 
such as organic fertilizer, worm food, perfume, and others can be more maximized. It is possible that Waturejo Village will be a pilot village in the management and utilization of livestock waste so that there will no longer found any livestock waste (cattle dung) dumped in the environment.

To help the community overcome the waste management problem in Waturejo Village, the researchers established an institution namely Rumah Pupuk Masyarakat (RPM) - the Community's Fertilizer House. Below is how the way of thinking presented by the Community's Fertilizer House. Based on the existing problems, the Community's Fertilizer House is really needed in overcoming the problem of livestock waste disposal that is done without considering the surrounding environment.

\subsection{Development Model of Community's Fertilizer House}

As an effort to overcome the problems often faced by the community, the researchers designed a model of Community's Fertilizer House. Community's Fertilizer House is a kind of institution engaged in the processing of livestock waste (cattle dung). This institution has a function to utilize the economic values of cattle dung, which had been wasted in the past. Institutionally, Community's Fertilizer House is also a place of dissemination of technology innovation among the community. The intervention is expected to be able to synergize with government efforts in maintaining the environment, which in this case particularly refers to the negative impacts of the mistaken livestock waste disposal.

\subsubsection{Rationalization of Community's Fertilizer House}

The presence of the Community's Fertilizer House would benefit the cattle breeders in Waturejo Village either directly or indirectly. It is known that the number of cattle in Waturejo Village approximately reached 1000 heads. If one cow can produce as much as $25 \mathrm{~kg}$ of dung, the total amount of dung produced will reach as much as $25,000 \mathrm{~kg}$. The waste of cattle dung, so far, has been only utilized into biogas and it has not covered all of the waste. The waste, if not utilized well, will be a serious problem. In other words, if the community can manage the waste appropriately, it will create a new economic source. In the following, we can see the rationalization of the Community's Fertilizer House.

\section{a. Economic Impact}

Dairy cattle farm business as the milk producer will certainly also waste cattle dung. The production of milk in Waturejo Village, so far, has been accommodated by the KUD but for the waste of cattle dung, there was no any party who could accommodate it. However, after the establishment of the Community's Fertilizer House in the environment of cattle breeders, the waste management problem of cattle dung can be solved. By the Community's Fertilizer House, the waste of cattle dung was accommodated into one place to be further processed into goods that have an economic value. Some products that were produced from or made of the waste of cattle dung included: manure (composted fertilizer), feed ingredient of worm cultivation, feed ingredient of catfish cultivation, air freshener, and so forth. The result of the sale of these products would then be shared with the breeders and the Community's Fertilizer House. The waste processing and utilization in the Community's Fertilizer House did not involve the breeders because the breeders did not have enough time in the waste management process of cattle dung. The breeders, in this case, more focused on the activity of looking for forage and milking.

b. Environmental Impact

Raising cows (cattle) is certainly not separated from the surrounding environment; the syndrome of $N I M B Y$-behavioral pattern stating that 'the most important is to not dispose of livestock waste around my own place' should be changed because the improper waste disposal will damage the environment. Grounding by this fact, the Community's Fertilizer House took a part as the container of the livestock waste. The existence of the Community's Fertilizer House minimized the amount of livestock waste. The existing waste was accommodated into one container and utilized into goods that have an economic value. Thus, the environmental damage due to the livestock waste disposal in Waturejo Village could be minimized.

According to (Dadan et al, 2013), the liquid waste of cattle dung can be improved using Spirulina $s p$. Based on this study, it was found that Spirulina $s p$. is able to decrease the content of organic waste (liquid waste of dairy cattle) for BOD, COD, and NO3 parameters, which respectively reach $92.98 \%, 92.5 \%$, and $54.79 \%$, as well as $94.07 \%, 94.46 \%$, and $54.63 \%$. The quality of liquid waste meets the Decree of the 
Minister of Environment No.51/ MENLH/ 10/ 1995) included in Group III.

\section{c. Educational Impact}

Education in the management of livestock waste as the effort to maintain the environment needs to be conducted among breeders. The lack of knowledge in managing and utilizing livestock waste is a classic issue that has often been encountered among communities. The high rate of population growth is also a factor influencing how people prefer to dispose of livestock waste instead of utilizing it.

If we look back to the past, people actually have utilized the waste of cattle dung into organic fertilizer. However, the process of making the waste into organic fertilizer using traditional methods has lead people to be lazy to apply it.

\subsubsection{Work Flow of Community's Fertilizer House}

The model of Community's Fertilizer House $(R P M)$ is conceptually a form of social engineering of rural economic institutions that utilize the institutionalization theory as the basis of approach. In this context, the system introduction to the economic life of the community is done through the introduction of the component functions of the Community's Fertilizer House until the components are recognized and become part of their socioeconomic life. Here is the conceptual framework of the Community's Fertilizer House (RPM) established in Waturejo Village.

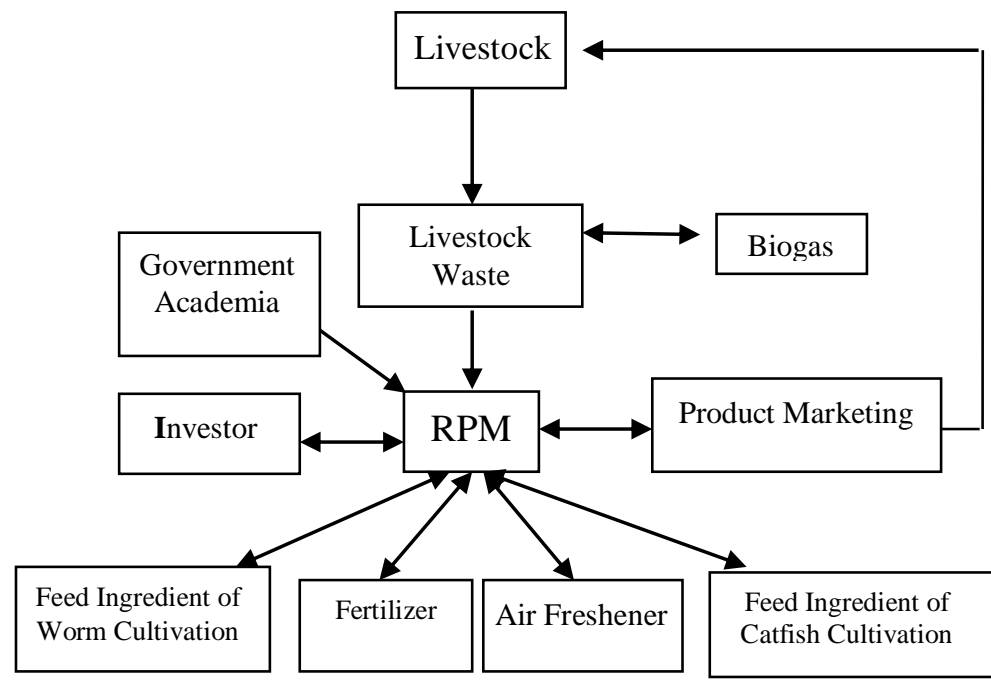

Figure 1. Conceptual Framework of RPM

The instruments are a guide that can be used or tested in other places in order to know the effectiveness in accordance with the same environmental conditions.
Figure 1. shows the pattern of how the Community's Fertilizer House (RPM) in Waturejo Village was applied. All the waste from the cattle breeding process was collected in one place, which was the Community's Fertilizer House (RPM). After being collected in the Community's Fertilizer House, the waste was then processed into various products that have an economic value. The products resulted from the waste covered the feed ingredient of worm cultivation, organic fertilizer, air freshener, and the feed ingredient of catfish cultivation. To make the Community's Fertilizer House run well, it requires the intervention and contribution of related parties such as the government, academics, and investors. Due to its economic value, it is highly important to find out a good alternative to make a good utilization of livestock waste. By the existence of the Community's Fertilizer House, it is expected that the community can minimize the improper disposal of livestock waste.

\section{Conclusion}

The community efforts in utilizing cattle dung are still limited to the needs. The community tends to only use cattle dung as a raw material for biogas and manure (organic fertilizer) while the remaining waste is thrown away to the environment, causing environmental damage. Moreover, the breeder community's contribution to utilize the cattle dung is also limited. The syndrome pattern of NIMBY is still highly inherent in the breeder community so that the community is less concerned about the environment.

The community contribution to protecting the environment from the negative impact caused by the livestock waste can be in the form of money or energy. In the form of money, the small breeders in Waturejo Village are willing to donate as much as $\mathrm{Rp} 10,000$ - Rp20,000 for the sake of environmental protection while in the form of energy, the community is willing to participate in every activity of environmental cleaning and protection.

The model designed to overcome the waste management problem of cattle dung is Rumah Pupuk Masyarakat (RPM) - Community's Fertilizer House. The existence of the Community's Fertilizer House helps the community to process the livestock waste that is not valuable into goods that have economic value. The Community's Fertilizer House is 
designed as the place of learning for the breeders about the importance of maintaining the environment.

\section{References}

Amang Fathurrohman, Muh. Aniar Hari, Aminatuz Zukhriyah dan, Moh. Awaludin Adam. 2016. Persepsi peternak sapi dalam pemanfaatan kotoran sapi menjadi bio-gas di Desa Sekarmojo Purwosari Pasuruan. Jurnal Ilmu-Ilmu Peternakan 25 (2): 36 42 ISSN: 0852-3581.

Ananto Kasworo, Munifatul Izzati, Kismartini. 2013. Daur Ulang Kotoran Ternak Sebagai Upaya Mendukung peternakan Sapi Potong Yang Berkelanjutan di Desa Jogonayan Kecamatan Ngablak Kabupaten Magelang. Prosiding Seminar Nasional Pengelolaan Sumberdaya Alam dan Lingkungan ISBN 978-602-17001-1-2.

Asep Setiawan, Tb. Benito,A.K dan Yuli, A.H. 2013. Pengelolaan Limbah Ternak pada Kawasan Budidaya Ternak Sapi Potong di Kabupaten Majalengka. Jurnal Ilmu Ternak, Vol.13, No. 1, Juni 2013.

BPS. 2014. Statistik. Indonesia. Malang.

Dadan, Roni Jantika, Tb Benito A. Kurnani, dan M.Wahyudi Lewaru. 2013. Perbaikan Kualitas Limbah Cair Peternakan Sapi Perah Oleh Spirulina Sp. Jurnal Akuatika Vol. II No. 2 September 2011, ISSN 08532523.

Fianda Revina Widyastuti, Purwanto, Hadiyanto. 2013. Potensi Biogas Melalui Pemanfaatan Limbah Padat Pada peternakan Sapi Perah Bangka Botanical Garden Pangkalpinang.

Indri A, Marina S , M. Ali M. 2015. Persepsi Masyarakat Terhadap Manfaat dan Dampak Negatif Limbah Peternakan Sapi Perah (Kasus di Desa Rancamulya Kecamatan Sumedang Utara Kabupaten Sumedang).

Juheini, N dan Sakryanu, KD. 1998. Perencanaan Sistem Usahatani Terpadu dalam Menunjang Pembangunan Pertanian yang Berkelanjutan : Kasus Kabupaten Magetan, Jawa Timur. Jurnal Agro Ekonomi (JAE) Vol. 17 (1). Pusat Penelitian Sosial Ekonomi Pertanian. Balitbangtan. Deptan. Jakarta.
Mirza Desfandi. 2015. Mewujudkan Masyarakat Berkarakter Peduli Lingkungan Melalui Program Adiwiyata. Copyright (C) 2015, SOSIO DIDAKTIKA, p-ISSN: 2356-1386, e-ISSN: 2442-9430.

Sholihul dan Wiwik. 2016. Pemanfaatan Limbah Kotoran Sapi Menjadi Pupuk Organik Sebagai Upaya Mendukung Usaha Peternakan Sapi Potong Di Kelompok Tani Ternak Mandiri Jaya Desa Moropelang Kec. Babat Kab.Lamongan. Axiologiya, Jurnal Pengabdian Masyarakat 2016, Vol.1.No.1.

Sugiyono. 2014. Metode Penelitian Pendidikan Pendekatan Kuantitatif, Kualitatif Dan R\&D.Bandung: Alfabeta. 